\title{
Seasonal variation of nutrients and hydrological conditions in the State Marine Park of Laje de Santos (SMPLS) and adjacent continental shelf areas (South Atlantic Ocean - Brazil)*
}

\author{
Elisabete de Santis Braga**, Vitor Gonsalez Chiozzini, Chiara Machado Vieira
}

\author{
Laboratory of Biogeochemistry of Nutrients, Micronutrients and Traces in Oceans \\ Instituto Oceanográfico da Universidade de São Paulo \\ (Praça do Oceanográfico, 191 - Butantã - São Paulo - SP - 05508120 - Brazil) \\ **Corresponding author: edsbraga@usp.br
}

\section{Abstract}

Marine parks constitute important areas for the conservation of marine life and the genetic heritage around the world. The creation of such marine parks must be accompanied by careful measures to guarantee the coexistence of natural biota and human activities in these systems. The State Marine Park of Laje de Santos (SMPLS) is so close to an industrial pole and urban area that its creation and maintenance is an example for humanity. However, no program has yet been installed for the monitoring of its biotic and abiotic water parameters. Thus, the objective of this study is to provide hydrological and hydrochemical parameters with emphasis on dissolved nutrients to establish a starting point for the monitoring of these waters. The presence of the South Atlantic Central Water (SACW) in the marine park during the spring and summer sampling periods was evidenced by the observation of low temperatures $\left(<17^{\circ} \mathrm{C}\right)$ associated with salinity around 35 at the bottom of the water column, indicating a thermohaline feature. The dissolved oxygen presented high values, with few data below $4 \mathrm{~mL} \mathrm{~L}^{-1}$ occurring at the bottom of the water column. The $\mathrm{pH}$ was always in accordance with marine values ( $\sim 8)$. Dissolved silicate and phosphate presented high values associated with inputs from the SACW intrusion, continental runoff and bottom resuspension processes, reaching maximum values of 15.86 and $1.23 \mu \mathrm{mol} \mathrm{L}^{-1}$, respectively. Nitrogen

\section{RESUMo}

Parques marinhos constituem áreas importantes para a conservação da vida marinha e do patrimônio genético em todo o mundo. A criação de tais parques deve ser acompanhada de medidas cuidadosas para garantir a coexistência de biota natural e de atividades humanas nestes sistemas. O Parque Estadual Marinho da Laje de Santos (PEMLS) situa-se próximo de um pólo industrial e uma área urbana, e sua criação e manutenção é um exemplo para a humanidade. No entanto, nenhum programa ainda não foi instalado para o acompanhamento dos parâmetros bióticos e abióticos da água. Assim, este estudo tem como objetivo fornecer parâmetros hidrológicos e hidroquímicos, com ênfase em nutrientes dissolvidos, para estabelecer um ponto de partida para o monitoramento dessas águas. A presença da Água Central do Antlântico Sul (ACAS) no parque marinho durante os períodos de amostragem de primavera e verão foi evidenciada pela observação de baixas temperaturas $\left(<17^{\circ} \mathrm{C}\right)$ associadas a valores de salinidade em torno de 35 no fundo da coluna de água, indicando uma característica termohalína típica. $\mathrm{O}$ oxigênio dissolvido apresentou valores elevados, com poucos dados abaixo de $4 \mathrm{ml} \mathrm{de} \mathrm{L}^{-1}$ ocorrendo no fundo da coluna de água. $\mathrm{O} \mathrm{pH}$ foi típico para valores marinhos $(\sim 8)$. Silicato e fosfato dissolvidos apresentaram valores elevados associados com a intrusão ACAS, escoamento continental e processos

Received: September 15, 2016

Approved: September 21, 2017

*Reference article of the Project MAPELMS - Environmental Monitoring of the State Marine Park of Laje de Santos

http://dx.doi.org/10.1590/S1679-87592017136806504 
compounds were also associated with a natural fertilization process by the presence of the SACW at the bottom of the water column, as evidenced by the high nitrate concentrations $\left(>7.00 \mu \mathrm{mol} \mathrm{L}^{-1}\right)$, while the concentration of $\mathrm{N}$-ammonium (maximum 9.86 $\mu \mathrm{mol} \mathrm{L} \mathrm{L}^{-1}$ ) demonstrated a rapid regeneration of the organic matter, mainly in the euphotic zone. Analysis of the data from summer periods revealed an annual difference, showing January 2014 to be drier than January 2015, which influenced the availability of some nutrients and the standard distribution of hydrochemical parameters in this region. The results of the distribution of hydrochemical parameters in the marine park confirms the preserved conditions of the seawater around the Laje de Santos, demonstrated by the excellent water quality, concluding the need to implant monitoring actions based on these reference data to preserve this important reserve of marine life.

Descriptors: Nutrients, Marine Park, Sazonal

Variation. de ressuspensão de sedimentos, atingindo valores máximos de 15,86 e 1,23 $\mu \mathrm{mol} \mathrm{L}^{-1}$, respectivamente. As formas inorgânicas nitrogenadas também foram associadas com um processo de fertilização natural pela presença do ACAS na parte inferior da coluna de água, como evidenciado pelas elevadas concentrações de nitrato $\left(>7,00 \mu \mathrm{mol} \mathrm{L}^{-1}\right)$, enquanto as concentrações de $\mathrm{N}$-amoniacal $\left(<9,86 \mu \mathrm{mol} \mathrm{L}^{-1}\right)$ demonstraram a regeneração rápida da matéria orgânica, principalmente na zona eufótica. A análise dos dados de períodos de verão revelou uma diferença anual, mostrando janeiro de 2014 mais seco do que janeiro de 2015, o que influenciou a disponibilidade de alguns nutrientes e os padrões de distribuição de parâmetros hidroquímicos nesta região. Os resultados observados quanto aos parâmetros hidroquímicos no parque marinho confirmam as condições preservadas da água do mar ao redor da Laje de Santos, caracterizada pela excelente qualidade da água, concluindo-se haver a necessidade de implantação de ações com base nesses dados de referência para o acompanhamento e a preservação desta importante reserva da vida marinha.

Descritores: Nutrientes, Parque Marinho, Variação Sazonal.

recreational and commercial uses that do not harm conservation, in our case, by observing the environmental data with values below those limits recognized as permissible by environmental laws (CONAMA, 2005).

The Laje de Santos Marine State Park is relatively near to the continent $(\sim 22 \mathrm{~nm})$, and its position is a matter of concern due to its proximity to a zone characterized by intense human activity. In this zone is located the Bay of Santos, which leads to the channel of the biggest port in Latin America - the port of Santos. Also located there is the most polluted industrial pole in Brazil, at Cubatão (CETESB, 2010), a sewage treatment plant and the Santos Submarine Outfall and an extensive urban area known as the Baixada Santista, with a population estimated at $1,765,277$ (IBGE, 2011). All this gives a particular significance to the park, and makes its preservation all the more important.

Santos Bay, by which the continental waters reach the ocean, is known for the pollution of its hydrological system which presents a considerable level of nutrients (BRAGA et al., 2000; SIQUEIRA et al., 2004; CETESB, 2010, SUTTI 
et al., 2016) and other contaminants (BÍCEGO et al., 2006; ABESSA et al., 2008, MARTINS et al., 2008; AZEVEDO; BRAGA, 2011) and also for the trace elements such as heavy metals, with a significant contribution of $\mathrm{Cr}$ and $\mathrm{Hg}$ (CETESB, 2010; SILVA et al., 2011), found in its sediments. Bacterial pollution - in the form of fecal coliforms - comes from a submarine waste disposal outlet, located in the central part of Santos Bay (BRAGA et al., 2000; MARTINS et al., 2008). The hydrodynamics of the region favor the dilution of the material introduced into the bay, minimizing the polluting effect both around the outlet it and in the park which lies at some distance from it (HARARI et al., 2008; CASTRO; LEE, 1995; CAMARGO et al., 2002).

In accordance with the objectives of the SMPLS project (Environmental Monitoring of the Laje de Santos Marine State Park of Lage de Santos), this study is an undertaking to provide hydrological and hydrochemical data such as will contribute to the evaluation of water quality and the identification of the marine processes associated with other environmental information to reinforce the implementation of the monitoring plan.

\section{MATERIAL AND METHODS}

Seawater samples were taken at 10 sampling points: two of them located near the entrance of Santos Bay, two others at an intermediate distance between the coast and the Marine State Park of Lage de Santos (MSPLS) and six distributed within the limits of the Park (Fig. 1).

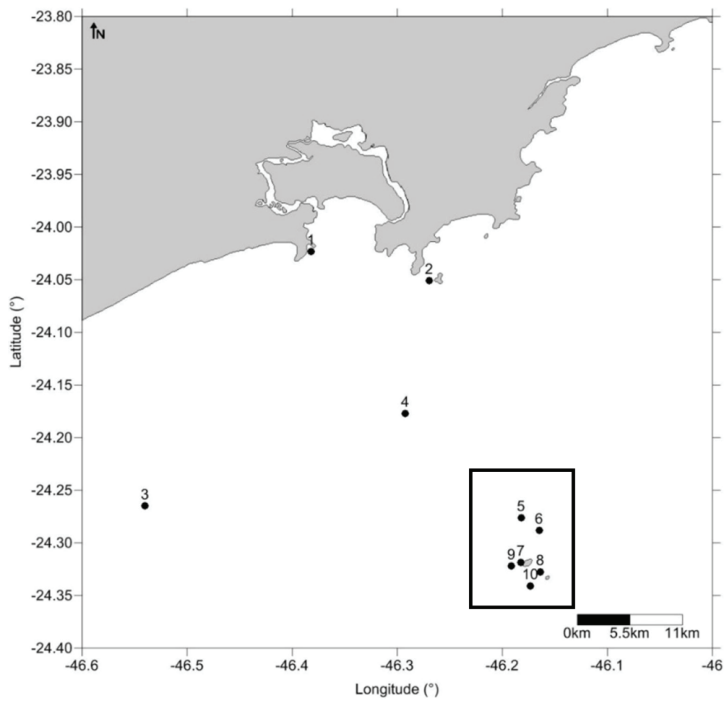

Figure 1. Localization of the sampling points on the continental shelf of São Paulo (Brazil) and in the State Marine Park of Lage de Santos (delimited by a small square).
More specifications of the sampling points: station 1 (Parcel dos Moleques); station 2 (Moela Island); station 3 (Parcel Dom Pedro); station 4 (close to deposit of dredged material); station 5 (Parcel do Bandolim); station 6 (parcel do Brilhante); station 7 (Laje de Santos); station 8 (Rocks); station 9 (Parcel do Sul); station 10 (Parcel Novo).

Rainfall information was obtained from a data base acquired from meteorological stations located in the city of Santos, and available at http://www.ciagro.sp.gov.br/ ciiagroonline/Quadros/QChuvaPeriodo.asp.

Transparency, temperature, salinity, dissolved oxygen, $\mathrm{pH}$ and nutrients were measured at each sampling point. A Secchi disk was employed to obtain the water transparency, which was used to calculate the extinction coefficient as recommended by POOLE and ATKINS (1929) and IDSO; GILBERT, 1974. Seawater temperature was taken using a reversing protected thermometer with a precision of $\pm 0.02^{\circ} \mathrm{C}$. Salinity was determined using an Beckman ${ }^{\circledR}$ RS10 inductive salinometer, with a precision of \pm 0.005 .

The seawater was sampled using Hydrobios ${ }^{\circledR}$ Nansen bottles. For dissolved oxygen determinations, the water was transferred to glass bottles with a known inner volume and ground-glass stopper that allows titration directly into the bottles after fixation. The samples were analyzed as soon as possible ( $<8 \mathrm{~h}$ from sampling), in accordance with the Winkler method (GRASSHOFF et al., 1999), by automated potentiometric titration using the Titrando, Metrohm ${ }^{\circledR}$. This method has an accuracy of $\pm 0.02 \mathrm{~mL} \mathrm{~L}^{-1}$ for concentrations of $2 \mathrm{~mL} \mathrm{~L}^{-1}$ and \pm 0.04 $\mathrm{mL} \mathrm{L}^{-1}$ for higher values. The $\mathrm{pH}$ samples were collected in glass bottles and measured using a Thermo Orion pHmeter, model P-210A, with a glass electrode in accordance with the recommendations given in AMINOT and CHAUSSEPIED (1983). For the nutrient analysis, the seawater samples were filtered through a Whatman $\mathrm{GF} / \mathrm{F}$ membrane, stored in polyethylene bottles and maintained at $-20^{\circ} \mathrm{C}$ until analysis in the laboratory. Dissolved phosphate and silicate were determined by the colorimetric method described in GRASSHOFF et al. (1999) using the BioSpectro SP 220 spectrophotometer and with a precision of $0.01 \mu \mathrm{mol} \mathrm{L}{ }^{-1}$ for $\mathrm{P}_{-} \mathrm{PO}_{4}{ }^{3-}$ and $0.02 \mu \mathrm{mol}$ $\mathrm{L}^{-1}$ for $\mathrm{Si}-\mathrm{Si}(\mathrm{OH})_{4}$. Dissolved nitrate was determined by reduction to nitrite in a $\mathrm{Cd} / \mathrm{Cu}$ column and both total nitrite and initial nitrite were determined by colorimetric analysis using a Bran-Luebbe ${ }^{\circledR}$ AutoAnalyzer, based on GRASSHOFF et al.(1983),TRÉGUER and Le CORRE (1975) and BRAGA (1997a; 1997b). Precisions were 0.01 $\mu \mathrm{mol} \mathrm{L}{ }^{-1}$ for $\mathrm{N}_{-} \mathrm{NO}_{2}{ }^{-}$and $0.02 \mu \mathrm{m} \mathrm{L}^{-1}$ for $\mathrm{N}^{-N_{3}}{ }_{3}^{-}$. Samples 
for the analysis of $\mathrm{N}$-ammonium were not filtered but were fixed immediately after sampling, while still on board. The N-ammonium concentrations were determined as described by TRÉGUER and LE CORRE (1975) with a precision of $0.05 \mu \mathrm{mol} \mathrm{L}{ }^{-1} \mathrm{~N}-\mathrm{NH}_{4}^{+}$.

All the data obtained were analyzed using the statistical and graphical programs of Excel $\AA$, Surfer $10 \AA$ and Past 3.11®. Pearson's correlation was applied to verify the degree of association between all the data to verify any possible cause/effect relation. The box plot treatment was used to verify the dispersion and asymmetry of data in each different seasonal period. The Ward method and Euclidian distance were used to verify the cluster grouping to ascertain the distinctive behavior of each sector.

\section{RESULTS}

The sampling surveys were undertaken in October 2013, January 2014, July 2014 and January 2015. These surveys corresponded to spring 2013, summer 2014, winter 2014 and summer 2015, respectively, and they will be thus referred to from now on. At this latitude, usually the winter is dry and the summer is rainy, but the summer of 2014 was exceptionally dry, as can be seen in figure 2 .
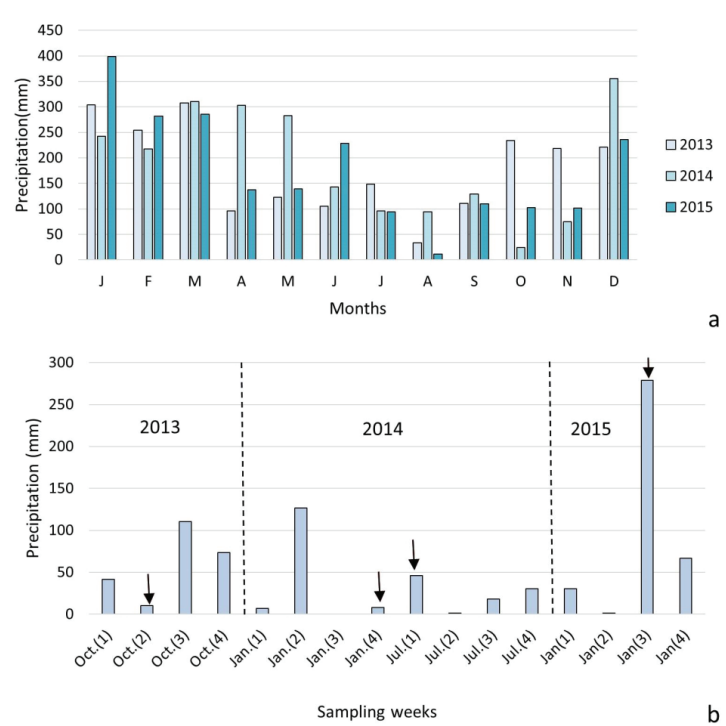

Figure 2. Monthly precipitation (a) and weekly precipitation (b) with the indication of the sampling periods (arrows), in the Santos region, São Paulo, Brazil.

The euphotic zone was estimated for each survey, it was observed that in spring 2013 the maximum depth of extinction of sunlight was around $14.5 \mathrm{~m}$ at station 4 and the minimum value was observed at station $1(2.5 \mathrm{~m})$. Station 1 is the nearest to the coast, and it comes therefore under considerable terrestrial influence. In summer 2014, minimum light penetration was observed at station $2(6.8 \mathrm{~m})$, also near the continental margin, the maximum layer being present at station $5(49.0 \mathrm{~m})$ on the platform, similarly to what occurred at the spring sampling, but deeper than on that occasion. As regards the winter, the minimum layer was found at station $1(4.1 \mathrm{~m})$ and the maximum at station $8(46.0 \mathrm{~m})$. The marine park and station 1 presented a minimum euphotic layer in all the periods, confirming the influence of terrestrial inputs and diminishing the quality of the sunlight available in this period; the great hydrodynamic activity contributing to the resuspension of sediments. In relation to summer 2015, greater values were observed, the shallowest layer being of $9.5 \mathrm{~m}$ (at stations 1 and 2) and the deepest layer reaching $48.7 \mathrm{~m}$ (st. 9) in the marine park. Both summers presented deeper euphotic layers, but at different stations, summer 2015 favoring sunlight penetration in the water column of the marine park, while summer 2014 presented the deepest average and median values (35.0 and 39.2, respectively) for series data (Fig. 3).
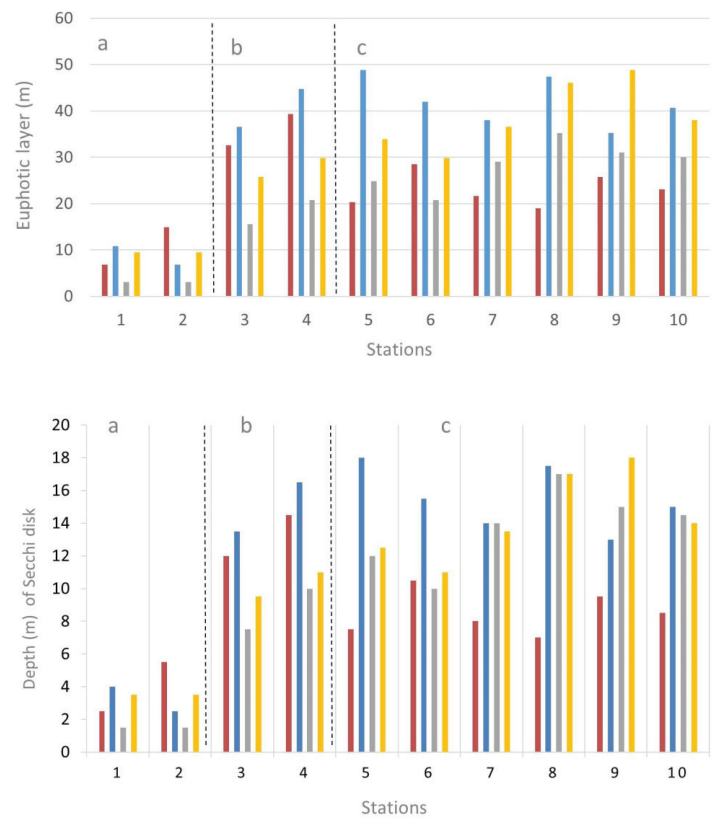

Figure 3. Estimated euphotic layer during the survey seasons at the stations on the continental shelf off Santos. Spring 2013 (red), summer 2014 (blue), winter 2014 (grey) and summer 2015 (yellow). Near the Santos Bay stations (a), intermediate stations (b) and marine park stations (c). 


\section{TEMPERATURE AND SALINITY}

Water temperature during the spring 2013 sampling ranged from $17.98^{\circ} \mathrm{C}$ (st. 6 - $40 \mathrm{~m}$ ) to $22.74^{\circ} \mathrm{C}$ (st. $1-0 \mathrm{~m}$ ) and presented an average of $20.16 \pm 1.36^{\circ} \mathrm{C}$. These values indicate a very cold situation for this region during spring (Fig. 4a), probably due to the high precipitation observed during the sampling (rainfall on 15 October was $76.5 \mathrm{~mm}$ ). In the January 2014 survey, summer period, the temperature varied from 15.73 to $30.40^{\circ} \mathrm{C}$, considering all the vertical profile, indicating stratification of the water column and intrusion of the South Atlantic Central Water (SACW - indicated by temperatures below $20^{\circ} \mathrm{C}$ at the bottom) on the continental shelf in this region (Fig. $4 \mathrm{~b}$ ). The small vertical variation of the temperature observed in the winter 2014 survey suggests the thermal homogeneity typical of this period (Fig. 4c). In the January 2015 sampling, presenting temperatures varying between 17.21 and $31.22{ }^{\circ} \mathrm{C}$, once again the vertical stratification of the water column was observed, understood as being due to the intrusion of the SACW (Fig. 4d). Overall, in the winter survey a thermal homogeneity prevailed, while in summer, the stratification was evident; there was, however, a difference between the two summer surveys - probably due to the dry weather observed in January 2014 (Fig. 4a-d).

Salinity values ranged approximately from 19 to 36 , the lowest ones being observed at stations 1 and 2, possibly because of their proximity to the continent and, consequently, to the influence of continental drainage. In the spring sampling period, most of the salinity values were low $(<34)$, stations 1 and 2, specifically, presenting the lowest values $(<22)$ (Fig. 4e), to be explained by the rain that occurred during the sampling period in an exceptionally rainy October (2013). Differently from the spring, the salinity values of the summer 2014 survey were higher (from around 34 to 36) (Fig. 4f), reflecting the atypically dry weather of that summer (2014), as mentioned above (Fig. 2). In the winter 2014 sampling period, salinity at the stations near the marine park showed values around 36 throughout the water column (Fig. 4g). However, the intermediate stations and those near the coast showed lower salinity values, indicating the influence of continental drainage even in a typically dry season. A similar pattern was observed in summer 2015, with higher salinity values at the marine park stations (values close to 36) and lower values at the intermediate stations and those near the coast (33.23 at station $1-5 \mathrm{~m})$ (Fig. 4h).

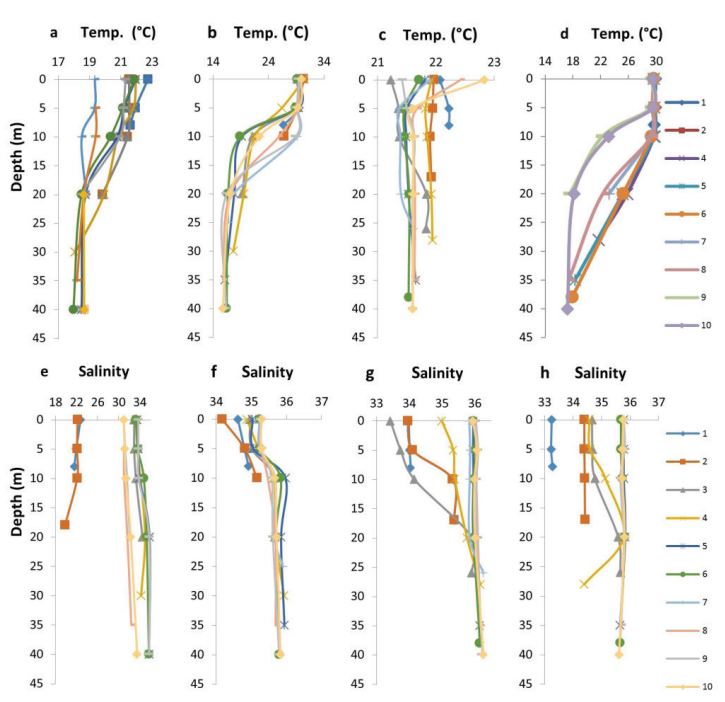

Figure 4. Vertical distribution of temperature (a to d) and salinity (e to h) in spring 2013 (a, e), summer 2014 (b, f), winter 2014 (c, g) and summer 2015(d, h) sampling periods at the stations on the continental shelf off Santos, Brazil.

\section{DISSOLVED OXYGEN AND PH}

Dissolved oxygen varied from 3.60 to $6.86 \mathrm{~mL} \mathrm{~L}^{-1}$ considering all seasons, stations and depths. Values obtained in the spring survey (Fig. 5a) showed a minimum concentration of $3.85 \mathrm{~mL} \mathrm{~L}^{-1}$ at the bottom of the water column at station $5(40 \mathrm{~m})$, in the marine park area, and at the intermediate stations (sts. 3 and 4). The maximum value was $6.57 \mathrm{~mL} \mathrm{~L}^{-1}$ at st. 7, located in the park area, at $5 \mathrm{~m}$ depth in the euphotic zone ( $>18 \mathrm{~m}$ in this period). The median value was $5.23 \mathrm{~mL} \mathrm{~L}^{-1}$, as expected for a period of higher primary production. In summer 2014 (Fig. 5b), DO showed a minimum of $3.60 \mathrm{~mL} \mathrm{~L}^{-1}$ at the bottom at station $1(8 \mathrm{~m})$, near the entrance of Santos Bay, the lowest value ever observed at any station throughout the survey. The maximum $\mathrm{DO}$ value in the same period was $6.86 \mathrm{~mL} \mathrm{~L}^{-1}$ at st. 2, at the opposite end from station 1 in the entrance of Santos Bay, at the surface of the water - as a result of airsea interaction and primary production. During the winter 2014 survey (Fig. 5c), the value of DO varied from 3.87 $\mathrm{mL} \mathrm{L}^{-1}$, observed at the bottom of the water column at station $2(17 \mathrm{~m})$, to $6.33 \mathrm{~mL} \mathrm{~L}^{-1}$, recorded at station 1 at $5 \mathrm{~m}$ depth. This variation was very similar to those found on the other surveys, especially during the spring sampling period, when most of the values were around $5.12 \mathrm{~mL} \mathrm{~L}^{-1}$, but it was mainly due to the lower surface temperature and 
more frequent wind in this period. As for the summer 2015 survey (Fig. 5d), the minimum DO value was $4.15 \mathrm{~mL} \mathrm{~L}^{-1}$, observed at the bottom of the water column (38 $\mathrm{m}$ depth) at station 8 inside the marine park, the maximum being $5.65 \mathrm{~mL} \mathrm{~L}^{-1}$, observed at station 10 , also in the marine park, at $20 \mathrm{~m}$ depth, still within the euphotic zone measured in this period. The median values in both summer sampling periods were similar, around $4.59 \mathrm{~mL} \mathrm{~L}^{-1}$.

The $\mathrm{pH}$ values measured were all superior to 8.11 at all the sampling points and depths, as was to be expected for oceanic waters (Fig. 5e-h). Considering all stations, the values ranged from 8.11 , observed in spring, to 8.48 , observed in the summer of 2014 , the median value being 8.29 , indicating no important freshwater or pollution input into the study area.

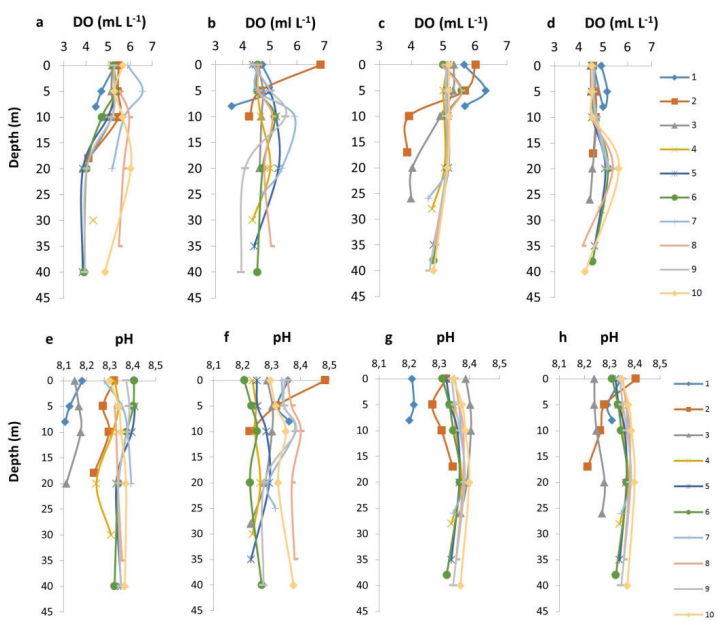

Figure 5. Vertical distribution of Dissolved Oxygen (DO) (a to d) and pH (e to h) in the spring 2013 (a; e), summer 2014 (b; f), winter 2014 (c; g), summer 2015(d; h) sampling periods at the stations on the continental shelf off Santos, Brazil.

\section{DisSOLVED NUTRIENTS}

In general, dissolved phosphate concentrations were low, even in the marine park, and values ranged from 0.01 to $1.23 \mu \mathrm{mol} \mathrm{L}{ }^{-1}$, considering all the sampling points and periods. In the spring 2013 sampling period (Fig. 6a), the values varied from $0.15 \mu \mathrm{mol} \mathrm{L}^{-1}$ to a maximum of 0.73 $\mu \mathrm{mol} \mathrm{L} \mathrm{L}^{-1}$ and the median values were around $0.39 \mu \mathrm{mol} \mathrm{L}{ }^{-1}$. In summer 2014 (Fig. 6b), phosphate concentrations varied from $0.01 \mu \mathrm{mol} \mathrm{L}{ }^{-1}$ (st. 9 at $5 \mathrm{~m}$ and $40 \mathrm{~m}$, st. 8 at $0 \mathrm{~m}$ and $5 \mathrm{~m}$ ) to a maximum of $1.23 \mu \mathrm{mol} \mathrm{L}{ }^{-1}$ (st. 2 at $0 \mathrm{~m}$ ), observed near the continent, the greater part of the data being around $0.35 \mu \mathrm{mol} \mathrm{L}{ }^{-1}$ (median). In the winter 2014 survey (Fig. $6 \mathrm{c})$, concentration varied between $0.19 \mu \mathrm{mol} \mathrm{L}-1$, measured at station 7 at $20 \mathrm{~m}$, and $1.23 \mu \mathrm{mol} \mathrm{L} \mathrm{L}^{-1}$, at station 2 at the surface of the seawater, with a median value of $0.25 \mu \mathrm{mol}$ $\mathrm{L}^{-1}$. In the summer 2015 survey (Fig. 6d), phosphate values varied from $0.05 \mu \mathrm{mol} \mathrm{L}-1$ (st. $4-5 \mathrm{~m}$ ) to $0.60 \mu \mathrm{mol} \mathrm{L}^{-1}$ (st. $1-0 \mathrm{~m})$ the median value being $0.16 \mu \mathrm{mol} \mathrm{L}^{-1}$.

Dissolved silicate concentrations in the study area varied from $0.30 \mu \mathrm{mol} \mathrm{L}^{-1}$ to $15.86 \mu \mathrm{mol} \mathrm{L}^{-1}$. In the spring 2013 sampling period (Fig. 6e), the mean silicate concentration was $5.52 \mu \mathrm{mol} \mathrm{L}{ }^{-1}$, the minimum value of 1.47 $\mu \mathrm{mol} \mathrm{L}{ }^{-1}$ being observed near Santos Bay at the seawater surface (st. $2-0 \mathrm{~m}$ ), and the maximum value of 13.19 $\mu \mathrm{mol} \mathrm{L} \mathrm{L}^{-1}$ being observed within the marine park area at the bottom ( space $=$ st. $5-40 \mathrm{~m}$ ). This maximum value was associated with a high nitrogen level, probably due to the slight presence of the South Atlantic Central Water (SACW) observed on the continental shelf in this period. In summer 2014 (Fig. 6f), the values varied from 1.11 $\mu \mathrm{mol} \mathrm{L}{ }^{-1}$ (st. 9 at $0 \mathrm{~m}$ ) to $11.75 \mu \mathrm{mol} \mathrm{L}^{-1}$ (st. 1 at $8 \mathrm{~m}$ ), with the highest value occurring again at the bottom of the water column but, in this case, near the continent and with a median value of $3.45 \mu \mathrm{mol} \mathrm{L}^{-1}$. In the winter 2014 sampling period (Fig. 6g), concentrations varied from 2.33 $\mu \mathrm{mol} \mathrm{L}{ }^{-1}$ (st. $7-20 \mathrm{~m}$ ) in the marine park to $13.67 \mu \mathrm{mol}$ $\mathrm{L}^{-1}$ (st. 2 at $17 \mathrm{~m}$ ), and the median value was $4.95 \mu \mathrm{mol} \mathrm{L}{ }^{-1}$. In the summer 2015 survey (Fig. 6h), dissolved silicate varied from the very low value of $0.30 \mu \mathrm{mol} \mathrm{L}^{-1}$ (st. $2-0 \mathrm{~m}$ ), observed near the coast, to $15.86 \mu \mathrm{mol} \mathrm{L}^{-1}$ (st. $5-40 \mathrm{~m}$ ). As in summer 2014, in this survey the median value was low $\left(3.40 \mu \mathrm{mol} \mathrm{L}^{-1}\right)$, probably associated with an intensive assimilation by organisms at the surface of the water in this period. No indication of erosion was observed near the coast since the highest values were associated mainly with bottom water.

Regarding the nitrogenous nutrients, N-ammonium showed values between 0.01 and $9.86 \mu \mathrm{mol} \mathrm{L}^{-1}$, considering all the sampling periods. In the spring 2014 survey (Fig. 7a), the minimum value was $0.06 \mu \mathrm{mol} \mathrm{L}-1$ at station 5 at $20 \mathrm{~m}$, within the marine park, where the euphotic zone reached approximately $20 \mathrm{~m}$ depth. The maximum value was $3.08 \mu \mathrm{mol}$ $\mathrm{L}^{-1}$, observed at station 1 at $0 \mathrm{~m}$, near the continent, where the existence of a discreet sewage input is known. The major part of the data were around 0.31 (median). In summer 2014 (Fig. 7b), the values were generally higher, with an average of $1.75 \mu \mathrm{mol} \mathrm{L}{ }^{-1}$, and varied from $0.95 \mu \mathrm{mol} \mathrm{L}-1$, at station 5 $(0 \mathrm{~m})$, to the maximum of $9.86 \mu \mathrm{mol} \mathrm{L}-1$, observed at station $7(25 \mathrm{~m})$, in the euphotic zone of this period. In the winter survey (Fig. 7c), N-ammonium values were in general lower $(<<0.5 \mu \mathrm{mol} \mathrm{L}-1)$, with a median of $0.08 \mu \mathrm{mol} \mathrm{L}^{-1}$, revealing 
a rapid recycling of the organic matter. The minimum value of $0.01 \mu \mathrm{mol} \mathrm{L}{ }^{-1}$ was observed at station 7 at 5 and $10 \mathrm{~m}$ depth and the maximum values were measured at station 4 at $10 \mathrm{~m}$

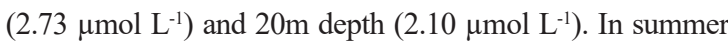
2015 (Fig. 7d), values ranged from $0.20 \mu \mathrm{mol} \mathrm{L}^{-1}$ (st. 5-20m) to $1.01 \mu \mathrm{mol} \mathrm{L}^{-1}$ (st. $1-0 \mathrm{~m}$ ) but the median value was 0.44 $\mu \mathrm{mol} \mathrm{L}{ }^{-1}$, indicating the availability of nitrogen to support regenerated production, as expected in this period.

Nitrite values varied from 0.02 to $2.41 \mu \mathrm{mol} \mathrm{L} \mathrm{L}^{-1}$ during this study. In spring 2014 (Fig. 7e), the values were low with a minimum of $0.02 \mu \mathrm{mol} \mathrm{L}-1$, observed at station 2 at $0 \mathrm{~m}$, and a maximum of $0.63 \mu \mathrm{mol} \mathrm{L}{ }^{-1}$, observed at station 8 (at $35 \mathrm{~m}$ ), located in the marine park. However, the median

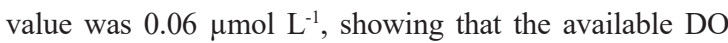
hinders the accumulation of nitrite in the study area. In the summer 2014 survey (Fig. 7f), the minimum value was 0.03 $\mu \mathrm{mol} \mathrm{L}{ }^{-1}$ (st. $7-0 \mathrm{~m}$ ), the maximum was 0.41 (st. 9 and 10 $-40 \mathrm{~m}$ ) and the median value was $0.05 \mu \mathrm{mol} \mathrm{L}{ }^{-1}$, showing the predominance of lower values. In winter 2014 (Fig. 7g), the minimum value was $0.08 \mu \mathrm{mol} \mathrm{L}^{-1}$, observed at station 7 (at $20 \mathrm{~m}$ depth) in the marine park, and the maximum value was $2.41 \mu \mathrm{mol} \mathrm{L}-1$, observed at station 2 (at $17 \mathrm{~m}$ depth) near the continent, with a median of $0.15 \mu \mathrm{mol} \mathrm{L}^{-1}$. In summer 2015 (Fig. 7h), the minimum value was $0.03 \mu \mathrm{mol} \mathrm{L}^{-1}$ (st. $10-0 \mathrm{~m}$ ) and the maximum $0.46 \mu \mathrm{mol} \mathrm{L}^{-1}$ (st. $8-35 \mathrm{~m}$ ), the variation being very similar to that obtained in the summer 2014 survey, with a median of $0.15 \mu \mathrm{mol} \mathrm{L}^{-1}$.

The most stable nitrogen form is nitrate and the values varied from 0.01 to $7.55 \mu \mathrm{mol} \mathrm{L} \mathrm{L}^{-1}$ in this study. In spring 2013 (Fig. 7i), the minimum value was $0.04 \mu \mathrm{mol} \mathrm{L}^{-1}$ (st. $7-5 \mathrm{~m}$ ) and the maximum $7.23 \mu \mathrm{mol} \mathrm{L^{-1 }}$, observed in the marine park at the bottom of the water column at station 6 (40m depth). The median value was $0.18 \mu \mathrm{mol} \mathrm{L} \mathrm{L}^{-1}$, a low value indicating an intense assimilation of this nutrient in the period studied, though the high values observed at the bottom of the water column suggest the penetration of the SACW onto the continental shelf. In summer 2014 (Fig. 7j), the minimum value was $0.06 \mu \mathrm{mol} \mathrm{L}^{-1}$ (st. 3, at 5 and $10 \mathrm{~m}$ depth), the maximum value was $7.56 \mu \mathrm{mol} \mathrm{L}^{-1}$ (st. 6 at $40 \mathrm{~m}$ depth), with median value of $0.28 \mu \mathrm{mol} \mathrm{L}^{-1}$. In winter 2014 (Fig. 7k), the minimum value was $0.01 \mu \mathrm{mol} \mathrm{L}^{-1}$, observed at station 9 (at 0,5 and 10m depth) and the maximum was observed near the continent at station $2(17 \mathrm{~m})$ at the bottom of the water column, the median value being $0.05 \mu \mathrm{mol}$ $\mathrm{L}^{-1}$. In general, the values in this sampling period were low, showing the homogeneity of the water column and with no evident regeneration process related to organic matter. In summer 2015 (Fig. 71), the values ranged from $0.10 \mu \mathrm{mol}$
$\mathrm{L}^{-1}$ (st. $7-5 \mathrm{~m}$ ) to $2.23 \mu \mathrm{mol} \mathrm{L}-1$ (st. 6- 40m) and the median value was $0.15 \mu \mathrm{mol} \mathrm{L}{ }^{-1}$. The influence of the SACW bottom intrusion in this sampling period on the concentration of nitrate at the stations located in the marine park was not evident as in the summer 2014 survey.
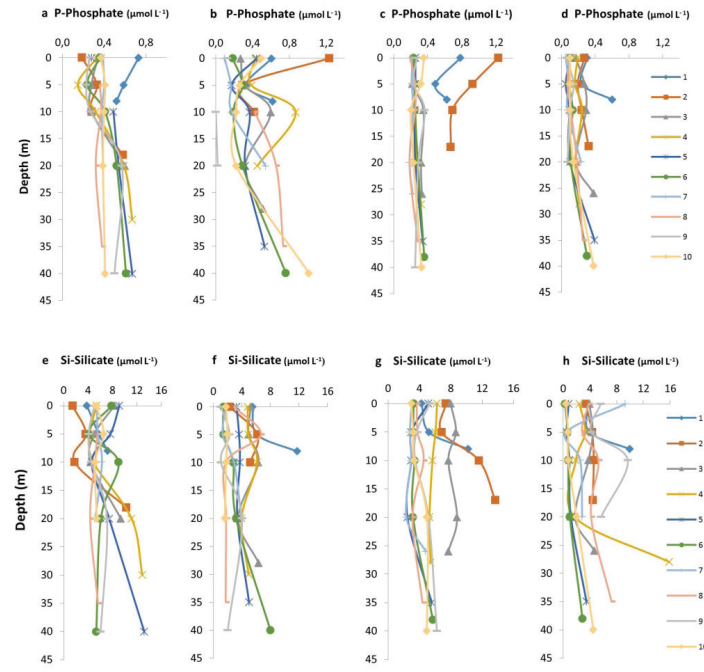

Figure 6. Vertical distribution of dissolved phosphate (a to d) and dissolved silicate (e to h) in the spring 2013 (a; e), summer 2014 (b; f), winter 2014 (c; g), summer 2015(d; h) at the stations on the continental shelf off Santos, Brazil.

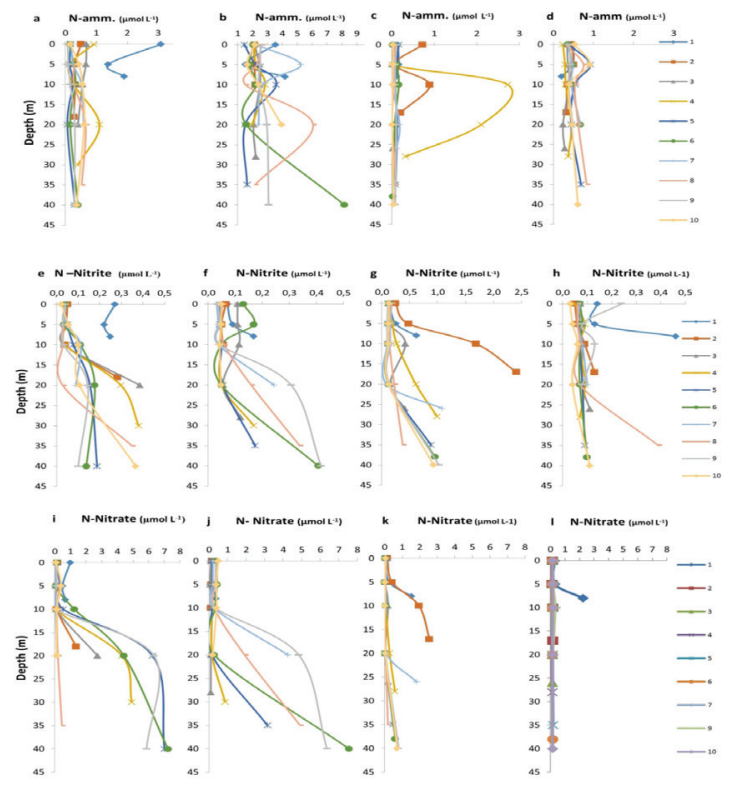

Figure 7. Vertical distribution of N-ammonium (a to d), N-nitrite (e to h) and N-nitrate (i to l) in spring 2013 (a; e; i), summer 2014 (b; f; j), winter 2014 (c; g; k), summer 2015(d; $h ; 1)$, at the stations on the continental shelf off Santos, Brazil. 
Dissolved Inorganic Nitrogen (DIN) varied between 0.14 and $15.63 \mu \mathrm{mol} \mathrm{L}{ }^{-1}$ and revealed a pool of nitrogen available for assimilation for primary production constituted mainly by nitrate and $\mathrm{N}$-ammonium. The water close to the bottom was influenced by the input of DIN from the South Atlantic Central Water (SACW) in the spring and summer 2014 surveys (Fig. 8a and b). In the winter sampling period, only stations 2, 4 and 7 (Fig. $8 \mathrm{c}$ ) presented an increase in $\mathrm{N}$ at the bottom of the water column, while in the summer 2015 survey (Fig. 8d) no important sign of enrichment was perceived in nitrogenous compounds.

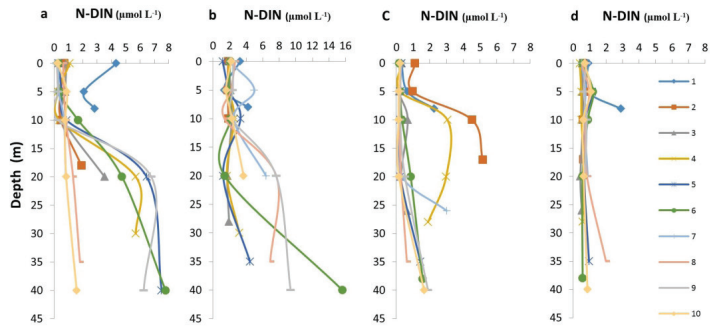

Figure 8. Vertical distribution of dissolved inorganic nitrogen (DIN) in spring 2013 (a), summer 2014 (b), winter 2014 (c), summer 2015(d) at the stations on the continental shelf off Santos, Brazil.

Suspended particulate matter measured during the spring 2013 survey (Fig. 9a) showed an average of 5.96 $\mathrm{mg} \mathrm{L}^{-1}$ and a large variation, the minimum value of 1.20 $\mathrm{mg} \mathrm{L}^{-1}$ being observed at station 5 (at $5 \mathrm{~m}$ depth) and the maximum value of $19.10 \mathrm{mg} \mathrm{L}^{-1}$ at station 1 at the bottom of the water column $(8-10 \mathrm{~m}$ depth). Further, figure $9 \mathrm{a}$ shows that SPM values were higher close to the bottom (26 - $40 \mathrm{~m}$ depth) at all the stations located in the marine park ( st. 5 to 10). As for the organic fraction (SPOM) (Fig. $9 \mathrm{e})$, the minimum value was observed at station 5 at $5 \mathrm{~m}$ depth, the maximum occurring at station 1 at the bottom of the water column ( $8 \mathrm{~m}$ depth), both values occurring at the same station and depth where the lowest and highest values of SPM were registered. In the case of the summer
2014 sampling period (Fig. 9b), the values were generally high, with concentrations mostly around $20 \mathrm{mg} \mathrm{L}^{-1}$, the maximum value found in the previous sampling period. This was probably due to an increase in the material coming from continental drainage and primary production, typical of a summer season in the area studied. In the winter 2014 survey (Fig. 9c), the values measured at stations 1 and 2 , the closest to the continent, were higher than the other stations'. The average value was $22.34 \pm 8.18 \mathrm{mg} \mathrm{L}^{-1}$ and the maximum value observed was $51.86 \mathrm{mg} \mathrm{L}^{-1}$ (st.1 $8 \mathrm{~m})$. In general, in the park, the values were around 19.68 $\mathrm{mg} \mathrm{L}^{-1}$ (median) with slightly higher values at station 7 (Laje de Santos) and station 9 (Parcel do Sul) at midwater.

The average value of SPOM (suspended particulate organic matter) observed in spring 2013 (Fig. 9e) was $2.06 \pm$ $1.37 \mathrm{mg} \mathrm{L}^{-1}$ and a large amount of SPOM was observed in deeper waters. This was not what was expected since the organic fraction usually presents higher values in shallower waters because of its association with chlorophyll, which may indicate the living biomass of this fraction within the photic zone. The SPOM values observed in the summer 2014 sampling period (Fig. 9f) were higher than those observed in the previous period, reflecting the important contribution of the production and degradation of organic matter during the summer, as well as that from anthropogenic sources. Station 6 (Parcel do Brilhante) and station 10 (Parcel Novo) presented the highest SPOM values, at the bottom of the water column and $5 \mathrm{~m}$ depths, respectively. In the case of SPOM in the winter survey (Fig. 9g), the data were relatively homogeneous at the park stations. The mean value was $5.91 \pm 2.04 \mathrm{mg} \mathrm{L}^{-1}$ and most of the data were around $5.57 \mathrm{mg} \mathrm{L}^{-1}$ (average). The highest value (12.43 mg $\mathrm{L}^{-1}$ ) was observed associated with the highest value of SPM in the same sampling period, at station 1 at $8 \mathrm{~m}$ depth.

In summer 2015, the SPM (Fig. 9d) concentrations were higher than those found in the summer 2014 survey, with an average of $29.91 \pm 3.43 \mathrm{mg} \mathrm{L}^{-1}$, most of the values being around $28.8 \mathrm{mg} \mathrm{L}^{-1}$. Organic matter (Fig. 9h) presented values with an average of $6.30 \pm 0.77 \mathrm{mg} \mathrm{L}^{-1}$, a very similar value to those of the summer 2014 survey, with the exception of the concentration at station 5 . 

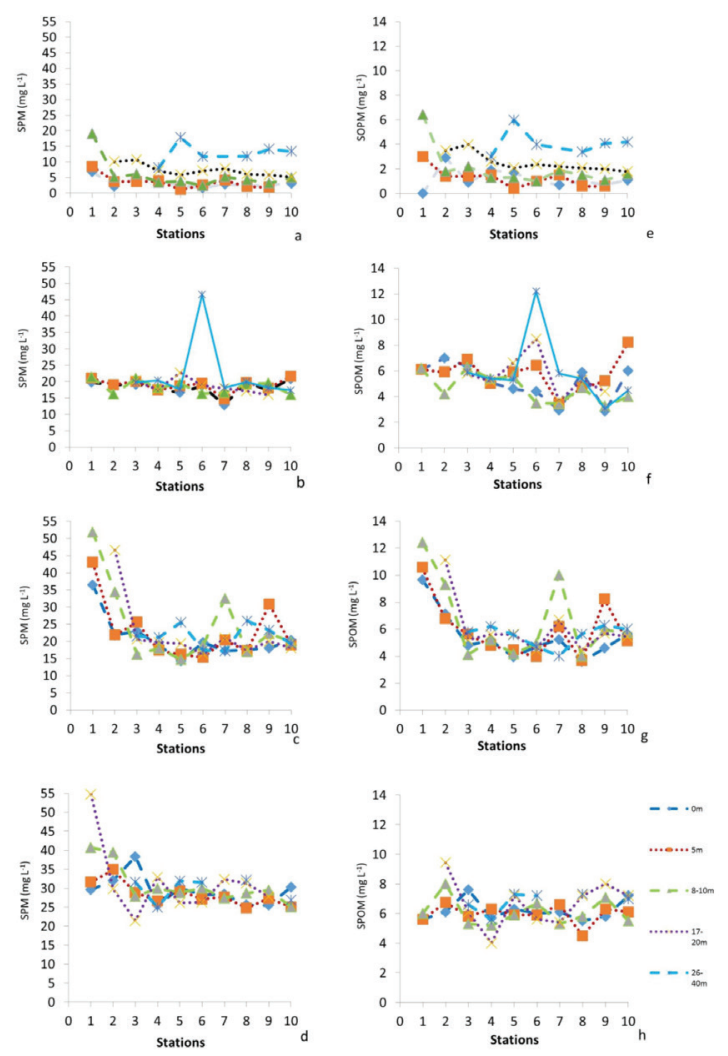

Figure 9. Concentrations of SPM (a to d) and SPOM (e to h) in the spring 2013 (a; e), summer 2014 (b; f), winter (c; g) and summer 2015 (d; h) surveys at the stations on the continental shelf off Santos, Brazil.
Table 1 shows the range of variation of the different water properties measured in this study. As already mentioned, the lowest temperatures observed in the summer of 2014 and 2015 sampling periods were associated with the presence of the SACW on the continental shelf. The lowest value of salinity was observed in spring 2013. The lowest value of DO occurred in the summer 2014 survey (an anomalous summer). The $\mathrm{pH}$ values measured in all the sampling periods were considered to lie within a normal range. The lowest concentrations of SPM occurred in spring 2013. The highest values of SPOM were observed in the summer and winter of 2014. N-ammonium concentrations showed the highest value in the summer 2014 survey. The highest value of nitrite occurred in winter 2014. Nitrate and DIN showed higher values in spring 2013 and summer 2014. Phosphate attained values slightly higher in the summer and winter 2014 surveys, as observed for the SPOM. Silicate presented a wide variation in all the periods studied.

Table 1. Variations of hydrological and hydrochemical parameters observed at the stations on the continental shelf off Santos. Spring $2013(n=44)$; Summer $2014(n=46)$; Winter $(n=46)$ and Summer $2015(n=45)$.

\begin{tabular}{lllll}
\hline Parameters & Spring 2013 & Summer 2014 & Winter 2014 & Summer 2015 \\
\hline Temperature $\left({ }^{\circ} \mathrm{C}\right)$ & $17.98-22.74$ & $14.73-30.42$ & $21.30-25.50$ & $17.21-31.22$ \\
Salinity & $30.93-35.85$ & $34.17-35.97$ & $32.92-35.76$ & $33.23-35.83$ \\
Dissolved Oxygen $\left(\mathrm{mL} \mathrm{L}^{-1}\right)$ & $3.85-6.57$ & $3.60-6.86$ & $3.87-6.33$ & $4.15-5.65$ \\
pH & $8.11-8.41$ & $8.21-8.48$ & $8.20-8.40$ & $8.21-8.41$ \\
SPM $\left(\mathrm{mg} \mathrm{L}^{-1}\right)$ & $1.20-19.10$ & $16.53-45.30$ & $14.38-51.86$ & $21.40-54.71$ \\
SPOM $\left(\mathrm{mg} \mathrm{L}^{-1}\right)$ & $0.40-6.44$ & $2.87-12.20$ & $3.60-12.43$ & $4.00-9.43$ \\
$\%$ SPOM & $2.9-42.2$ & $12.88-46.56$ & $20.45-32.62$ & $14.74-26.02$ \\
N-ammonium $\left(\mu \mathrm{mol} \mathrm{L}^{-1}\right)$ & $0.06-3.08$ & $0.95-9.86$ & $0.00-2.73$ & $0.20-1.01$ \\
N-Nitrite $\left(\mu \mathrm{mol} \mathrm{L}{ }^{-1}\right)$ & $0.02-0.63$ & $0.03-0.42$ & $0.08-2.41$ & $0.03-0.46$ \\
\hline
\end{tabular}

\section{DISCUSSION}

The southeastern Brazilian continental shelf is wide, attaining as much as $200 \mathrm{~km}$ in width of São Paulo, and situated in the central region of the São Paulo Bight $\left(23.5^{\circ}-27^{\circ} \mathrm{S}\right)$. Throughout this area, the Brazilian Current transports Tropical Water (TW) and South Atlantic Central Water (SACW) in a south-southwesterly direction (GODOI et al., 2006). Events associated with the 
incursion of the SACW (enriched with nutrients) onto the southeastern continental shelf have been recorded by some authors (Matsuura, 1986; Braga; Muller, 1998, CERDA; CASTRO FILHO, 2014; MOSER et al., 2016) and it represents a fertilization of this region. This fertilization contributes to the survival of species by supporting primary production when light is sufficient and mixture and diffusion processes occur. This intrusion is more frequent during summer periods. VALENTIN (1992) showed the correlation of the upwelling at Cabo Frio, in a more northerly region than this present study area, with primary production. The penetration of SACW onto the southeastern Brazilian continental shelf is facilitated by various mechanisms such as Ekman's transport and pumping, internal waves, and cyclonic eddies (CERDA; CASTRO, 2014).

In this present study, the thermohaline characterization of the waters (Fig. 10) revealed a horizontal spreading during the summer sampling periods, with low temperatures associated with the presence of the SACW on the continental shelf; a vertical spreading during the spring period, forced by low salinity due to the rainfall observed during the sampling activities; and two groups in the winter sampling period, one more saline than the other maybe by virtue of the annual difference in precipitation during this period. The themohaline values associated with the presence of SACW during the summer samplings (January) ranged in 2014 from 15.73 to $18.75^{\circ} \mathrm{C}$ and 35.61 to 35.93 and in 2015 from 17.21 to $18.30^{\circ} \mathrm{C}$ and 35.61 to 35.80 for temperature and salinity, respectively. The values observed were slightly above the thermohaline index for the SACW (35.5 of salinity and $15^{\circ} \mathrm{C}$ of temperature) observed by BRAGA and MULLER (1998) during a spring intrusion. The dynamic of this water mass is important for water fertilization and for renewal of the bottom water in the park region. In relation to monitoring actions, the water in the marine park was classified as saline $(>30)$ during all the surveys conducted in accordance with the Brazilian Environmental Laws (CONAMA, 2005) which prescribe limits for environmental variables in assessing water quality.

The rainfall during this study confirms the dry and wet seasons typical of the area studied with precipitation of $111 \mathrm{~mm}$ in September 2013, $241 \mathrm{~mm}$ in November 2013, $242 \mathrm{~mm}$ in January 2014, $99 \mathrm{~mm}$ in July 2014 and 399 $\mathrm{mm}$ in January 2015. These values evidence the difference in precipitation between January 2014 and 2015 that influenced some hydrochemical parameters. This is an alert regarding the interannual variation of properties by virtue in function ert fordifference oof climate change.

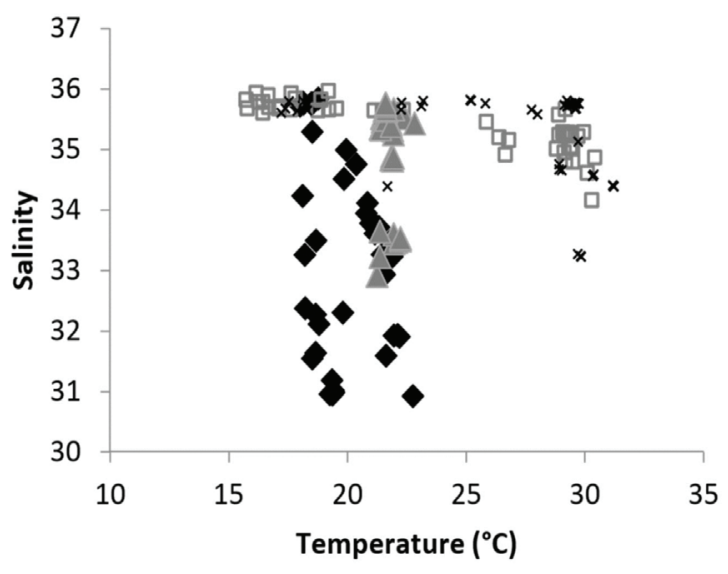

Figure 10. Temperature versus salinity data obtained during spring 2013(diamond shape); summer 2014 (square); winter 2014 (triangle) and summer 2015 (cross) surveys on the continental shelf off Santos -São Paulo, Brazil.

The light penetration depth was in general considerable $(>10 \mathrm{~m})$ at the stations furthermost from the coast within the marine park, and under the influence of the seasonal rainfall regime. The stations located in the marine park showed the lowest values of light penetration depth during the most productive period (spring), indicating the interference of organic production and recycling of organic matter in the euphotic zone. At these stations, the scattering of light was linked to an increase in the organic matter below $20 \mathrm{~m}$ depth, possibly associated with both primary production and detritus production/ regeneration in the euphotic layer above, resuspension processes and an oceanic dynamic with little or no input from terrestrial process. The absorption of light by colored dissolved organic matter (CDOM), phytoplankton and nanoalgal matter is an important property in coastal and oceanic studies indicating the source of the suspended matter and its association with the predominant process (BABIN et al., 2003). As for stations 3 to 6, light penetration was more influenced by annual summer differences. In relation to stations 1 and 2, located at the entrance to Santos Bay, some alteration in light penetration is to be expected due to the possibility of the input of substances from rivers, atmospheric deposition, effluents and surface water runoff. This area normally presents a high gradient of chemical substance concentrations submitted to transformation, retention and elimination (LIVINGSTONE, 1998; CETESB, 2001; SIQUEIRA et al., 2004; MOSER et al., 2005). 

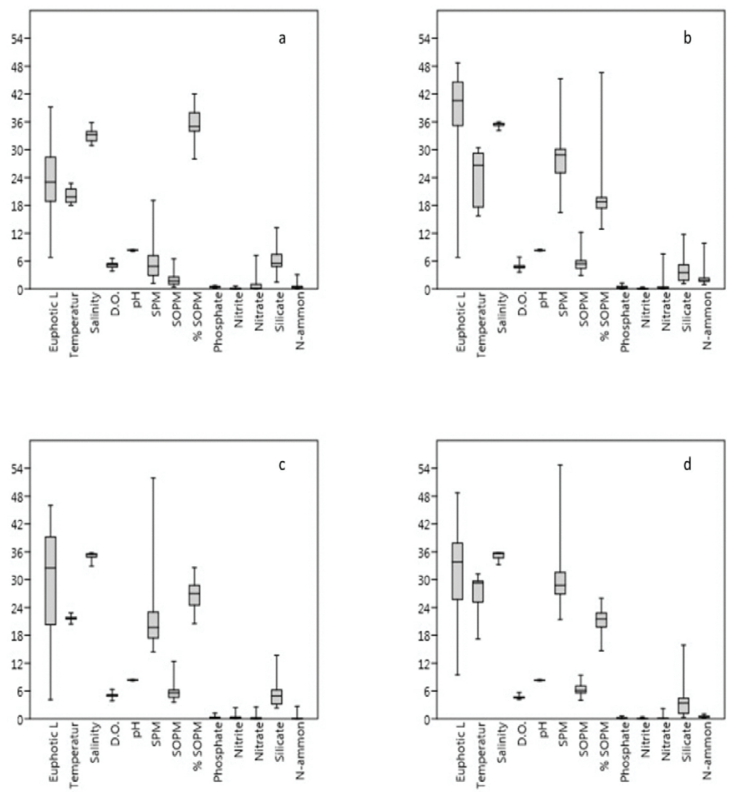

Figure 11. Box plot of all the data obtained during the spring 2013 (a); summer 2014 (b), winter 2014 (c) and summer 2015(d) sampling periods on the continental shelf off Santos, Brazil.

In the light of all the data obtained, including those on temperature and salinity, it is possible to verify seasonal differences in the limits, average and median patterns. The analysis of the box plots revealed the most considerable euphotic layer observed in the summer 2014 survey (Fig. 11b), the lower and homogeneous water temperature in the winter 2014 survey (Fig. 11c), the higher and homogenous salinity in summer 2014 (Fig. 11b), the mostly homogeneous values of dissolved oxygen in summer 2015 (Fig. 11d) and the constant $\mathrm{pH}$ values in all the sampling periods.

No high posphate values were observed, the most noticeable of them occurring in summer 2014 and winter 2014 (Fig. 11, b and c). PRASTKA et al. (1998), using a $P$ variation model, suggest that polluted estuaries should tend to serve as a sink of $\mathrm{P}$ and non-polluted ones to act as a source of $\mathrm{P}$ for adjacent water. The low values of $\mathrm{P}$ in the water at all the stations of the marine park, and also near the coast, could thus confirm the P retention capacity of the Santos estuary. In the Bay of Santos, AGUIAR and BRAGA (2007) observed a variation from 0.46 to 2.85 $\mu \mathrm{M}$ DIP at the neap tide and from 0.40 to $1.19 \mu \mathrm{M}$ at the spring tide during a winter period. In this present study, the maximum DIP was $1.23 \mu \mathrm{M}$, showing an oceanward dilution in surface water and an enrichment at the bottom of the water column within the marine park, due to oceanic fertilization and not to any eutrophication process. However, the polluted system retains the excess of phosphate input from the Santos/São Vicente Estuary reported by the above-mentioned authors in the Santos Channel.

Nitrite concentrations at nearby stations were more evident in winter 2014 (Fig. 11c). Nitrate was more pronounced in spring, associated with the presence of SACW (Fig. 11a). Ammonium was more evident during the atypical summer of 2014, associated with rapid regeneration (Fig. 11b). Silicate was slightly higher in spring because of the rain which fell during the sampling (Fig. 11a).

AZEVEDO and BRAGA (2011), in the light of the possibility of a seasonal evolution, ascertained that nitrate was high in summer in the Santos Channel (approximately $10-30 \mu \mathrm{M})$ and that a dilution occurred in the direction of the Bay of Santos (of approximately 2-5 $\mu \mathrm{mol} \mathrm{L} \mathrm{L}^{-1}$ ). The higher nitrite values were attributed to denitrification and/ or the oxidation of $\mathrm{N}$-ammonium when dissolved oxygen was low, also indicating the denitrification of nitrate. In the case of the marine park, oxygen was high at the surface of the sea and at mid-water. Some low concentrations of nitrite were observed near the continent and at the bottom of the water column associated with regeneration processes. At stations 1 and 2, at the bottom, the transformation of material introduced by the coastal system is responsible for this. The nitrite presented low concentrations and $\mathrm{N}$-ammonium a small signal during the winter survey, demonstrating that the regeneration of organic matter is important in this period for the recuperation of the stock for the next spring, as has been observed by other studies (GIANESELLA et al., 2005, MOSER et al., 2005; AZEVEDO; BRAGA, 2011). 


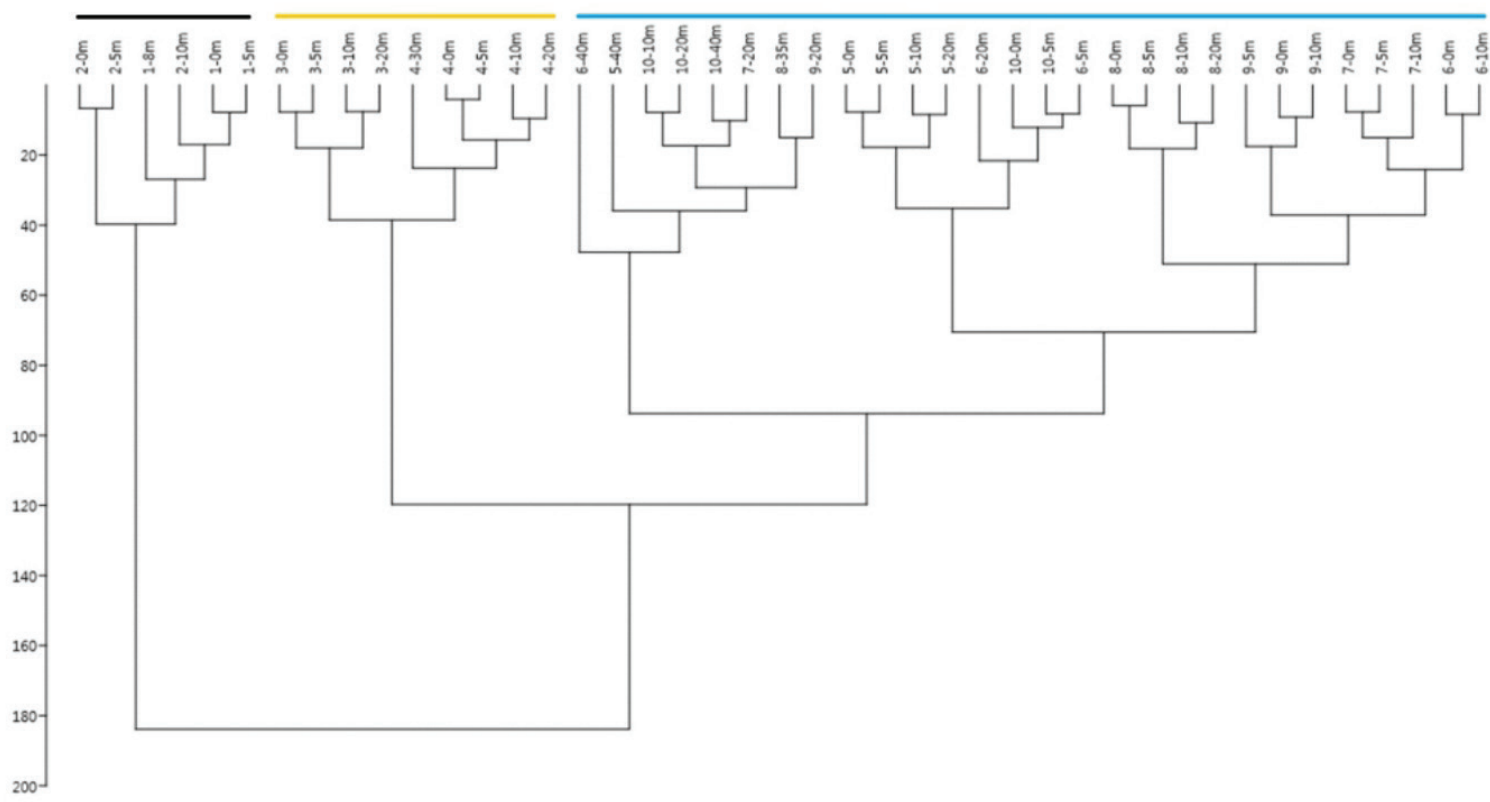

Figure 12. Dendrogram showing the groups of stations on the continental shelf off Santos.

The statistical treatment, considering the Euclidian distance for all the parameters and single linkage shown in figure 12, evidences the grouping of the shallow (sts 1 and 2) and near coastal stations (sts 3 and 4), distinguishing them from those distant from the coast (the park stations), more subject to the influence of the oceanic dynamic, as also to the presence of the SACW. In some periods stations 3 and 4 present similarities with the park stations by virtue of the movement of deeper waters onto the continental shelf, mainly during summer time, when the SACW ascends and penetrates the shallow areas of the continental shelf. In general, considering all the stations and periods studied, three groups of stations stood out as being characterized by oceanic and/or terrestrial factors and also for their environmental preservation status.

It was clear that the stations near the continent were in shallower water than the others and more influenced by terrestrial and anthropogenic inputs, as well as by the natural condition of a bay fed by an estuarine system (Santos
Bay and the Santos-São Vicente Estuary). The intermediate stations, located on the continental shelf between the continent and the marine park, were subject to different hydrodynamic and human influences. Ultimately, the marine park stations were subject to those particular conditions appropriate to the maintenance of the diversity of life observed there.

Figure 13 presents the highest temperature which occurred during the summer sampling period at all the stations, despite the stratification and the presence of cold water at the bottom of the marine park stations. Another observation is that salinity presented high values at the stations far from the coast throughout the study period. Silicate and phosphate gain importance at the stations near the coast. Nitrate increased during the spring survey at the intermediate stations and during the spring and summer (2014) in the marine park stations due to the SACW's influence. $\mathrm{N}$-ammonium played an important role in regeneration processes mainly in summer 2014 (an atypically dry period) at all the stations. 
Table 2. Pearson's correlation between the data obtained in all the sampling periods of this study, with $\mathrm{p}<0.05$ ( $95 \%$ ).

\begin{tabular}{|c|c|c|c|c|c|c|c|c|c|c|c|c|c|}
\hline & 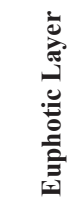 & 完 & 氙 & 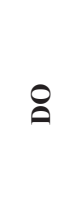 & 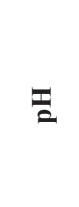 & $\sum_{\infty}$ & 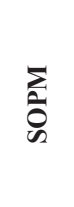 & $\begin{array}{l}\sum_{i} \\
\overline{0} \\
\overbrace{}^{\circ} \\
0^{\circ}\end{array}$ & $\frac{\dot{a}}{\frac{1}{0}}$ & 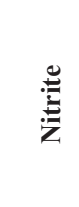 & 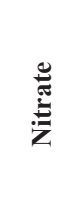 & 莺 & 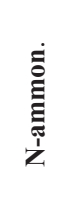 \\
\hline Euphotic Layer & 1.00 & & & & & & & & & & & & \\
\hline Temperature & 0.25 & 1.00 & & & & & & & & & & & \\
\hline Salinity & 0.62 & 0.15 & 1 & & & & & & & & & & \\
\hline DO & -0.62 & -0.12 & -0.47 & 1.00 & & & & & & & & & \\
\hline $\mathrm{pH}$ & -0.15 & -0.12 & 0.10 & 0.22 & 1.00 & & & & & & & & \\
\hline SPM & 0.08 & 0.42 & 0.52 & -0.23 & -0.20 & 1.00 & & & & & & & \\
\hline SPOM & -0.03 & 0.25 & 0.49 & -0.21 & -0.17 & 0.89 & 1.00 & & & & & & \\
\hline$\%$ SOPM & -0.31 & -0.46 & -0.54 & 0.22 & 0.07 & -0.75 & -0.45 & 1.00 & & & & & \\
\hline Phosphate & -0.62 & -0.35 & -0.24 & 0.05 & -0.10 & -0.04 & 0.07 & 0.24 & 1.00 & & & & \\
\hline Nitrite & -0.16 & -0.19 & 0.07 & -0.26 & 0.04 & 0.15 & 0.29 & 0.05 & 0.28 & 1.00 & & & \\
\hline Nitrate & -0.08 & -0.38 & 0.17 & -0.43 & -0.05 & -0.10 & -0.01 & 0.16 & 0.40 & 0.26 & 1.00 & & \\
\hline Silicate & -0.17 & -0.32 & -0.26 & -0.21 & 0.01 & -0.14 & -0.01 & 0.35 & 0.46 & 0.42 & 0.33 & 1.00 & \\
\hline N-ammon. & -0.05 & -0.07 & 0.17 & -0.15 & -0.12 & 0.21 & 0.13 & -0.25 & 0.19 & -0.05 & 0.24 & -0.08 & 1.00 \\
\hline
\end{tabular}

Observing Pearson's correlation (Tab. 2), a high and positive correlation $(r=0.62)$ was observed between the salinity and depth of the euphotic zone that confirms the influence of the terrestrial input with the optical properties associated with fresh water contributions in terms of the penetration of light in the water column, as seen by the relatively greater depth of the euphotic zone at the more external stations, particularly those in the marine park, than at stations 1 and 2. At stations 5 to 10, a deeper euphotic zone was observed, reaching down to approximately $49 \mathrm{~m}$ in January 2014.

The $\mathrm{pH}$ values exhibit little variation due to the buffering capacity of seawater and presented a correlation with dissolved oxygen. The SPM and SPOM presented significant correlations with salinity that evidence the presence of particulate matter at all the stations, in both organic and inorganic forms, but the percentage of suspended organic particulate matter decreases with salinity, contributing to the natural conditions at the external stations indicating the presence of a fraction of organic matter resulting from primary production. Dissolved phosphate showed a negative correlation with the euphotic layer, temperature and salinity, indicating its removal by primary production at the sea surface and the euphotic zone, and a positive correlation with the percentage of SPOM, indicating production of organic matter. Nitrite showed an inverse relation with DO, indicating the consumption of oxygen to oxidize nitrate, and a positive correlation with phosphate. Nitrate presented an inverse relation to temperature and a direct one with salinity, phosphate and silicate, indicating the influence of SACW at the bottom of the water column, associated with organic matter, and a negative correlation with DO, probably due to regeneration processes associated with deep waters. Silicate presented an inverse correlation with temperature, salinity and dissolved oxygen and a positive relation with phosphate, nitrate and nitrite, suggesting the influence of a terrestrial source of the material. Ammonium showed an inverse correlation with DO and $\mathrm{SPOM} \%$, indicating its generation from the oxidation of organic matter. The above-mentioned regeneration process associated with the intrusion of the SACW onto the continental shelf has also been reported by AIDAR et al. (1993), BRAGA and MULLER (1998), BRAGA; NIENCHESKI (2006) and BRAGA et al. (2008). The penetration of the SACW onto the Southeastern Brazilian continental shelf is facilitated by various mechanisms such as Ekman's transport and pumping, internal waves, and cyclonic eddies (CERDA; CASTRO FILHO, 2013). 

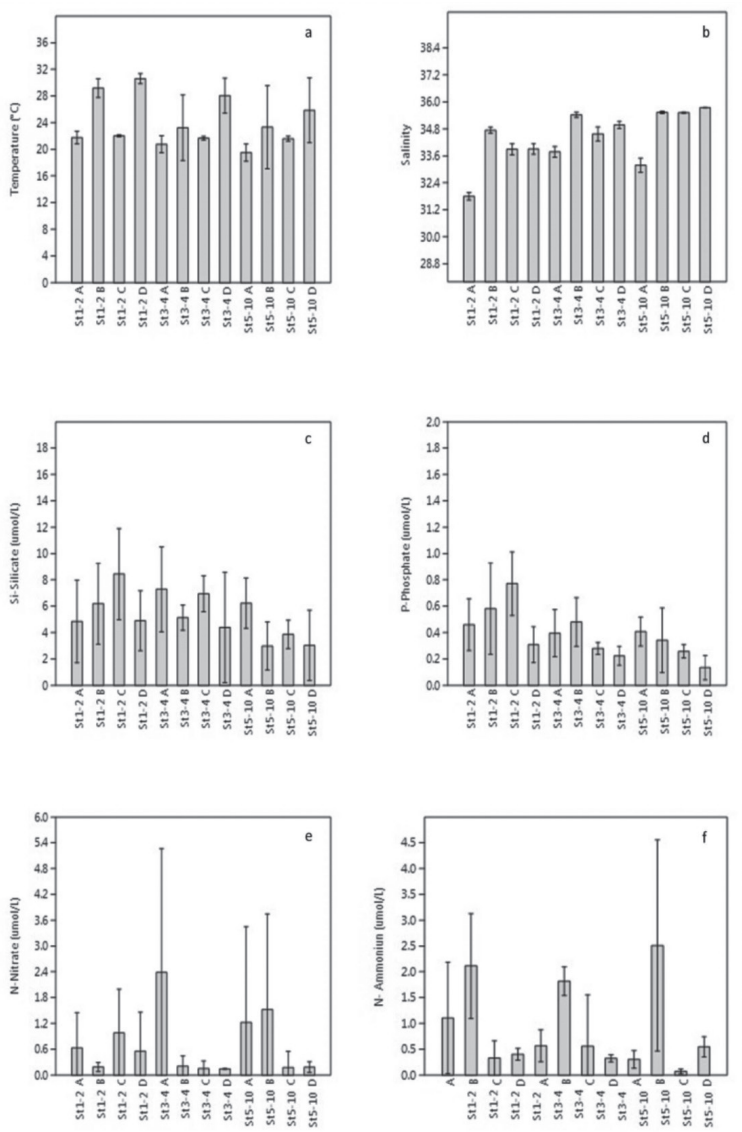

Figure 13. Variation of temperature (a), salinity (b), silicate (c), phosphate (d), nitrate (e) and ammonium (f) of the groups of stations near the coast (sts. 1-2), intermediate (sts. 3-4) and marine park (st. 5-10), during the spring 2013 (A), summer 2014(B), winter 2014 (C) and summer 2015 (D) surveys.

\section{CONCLUSION}

In the studied area, the contrast of warm surface water with the influence of the SACW at the bottom of the water column promotes an evident stratification during the summer periods which is also responsible for differences in the chemical properties at the bottom, but in accordance with expectations and with great importance for the fertilization of the sea. No indication of pollution in the Marine Park region was observed in terms of the chemical properties studied. At the points located near the continent signs of pollution were detected, but their presence does not yet extend as far as the marine park.

This study concludes that the area in which the marine park is located, although relatively near a coastal source of pollution, is still protected by virtue of the oceanic hydrodynamic and natural fertilization. The negative continental influence, regardless of the season, is negligible. This ensures the preservation of the water quality in the marine park while the practically non-existent influence of abrupt climate change still persists in the region. Even so, it is clearly necessary to establish a monitoring program in order to follow through and even avoid other kinds of impact, since a marine park must by definition provide for a variety of uses.

\section{ACKNOWLEDGEMENTS}

The authors would like to thank Petrobras, IBAMA and FUNDESPA for supporting this study and the LabnutIOUSP group for their contribution during the undertaking of the research activities. We would also thank Dr. Glaucia Berbel for her preparation of some of the graphs and Beatriz F. Scigliano MSc. and Bachelor Cassio Edelstein for their support in sampling and analysis activities.

\section{REFERENCES}

AIDAR E.; GAETA, S. A.; GIANESELLA-GALVÃO, S. M. F.; KUTNER, M. B. B.; TEIXEIRA, C. Ecossistema costeiro subtropical, fitoplâncton e clorofila-a, e suas relações com as condições oceanográficas na região de Ubatuba, SP. In: A. M. S. Vanin (Ed), Estrutura e função do ecossistema de plataforma continental do Atlântico Sul Brasileiro. Publçs. Esp. Inst. Oceanogr., v. 10, p. 9-43, 1993.

AGUIAR, V. M. C.; BRAGA, E. S. Seasonal and tidal variability of phosphorus along a salinity gradiente in the heavily polluted estuarine system of Santos/São Vicente - São Paulo, Brazil. Mar. Poll. Bull., v. 54, p. 464-488, 2007.

ABESSA, D. M. S.; CARR, R. S.; SOUSA, E. C. P. M.; RACHID, B. R. F.; ZARONI, L. P.; PINTO, Y. A.; GASPARRO, M. R.; BÍCEGO, M. C.; HORTELLANI, M. A.; SARKIS, J. E. S. Integrative ecotoxicological assessment of a complex tropical estuarine system. In: HOFER, T. N. (Ed.). Marine pollution: new research. Hauppauge: Nova Science; (Science, Technology \& Business). Lancaster: Gazelle, 2008. p. 1-36.

AMADO-FILHO, G. M.; HORTA, P. A.; BRASILEIRO, P. S.; FUJII, M. T.; BARRETO, M. B. B. Subtidal benthic marine algae of the Marine State Park of Laje de Santos (São Paulo, Brazil). Braz. J. Oceanogr., v. 54, p. 225-234, 2006.

AMINOT, A.; CHAUSSEPIED, M. Manuel des analyses chimiques en milieu marin. 1 ère ed. Brest Cedex, Centre National pour l' Exploitation des Océans (CNEXO), 1983. 395 p.

AZEVEDO, J. S.; BRAGA, E. S. Caracterização hidroquímica para qualificação ambiental dos estuários de Santos-São Vicente e Cananéia. Arq. Ciênc. Mar, Fortaleza, v. 444, p.52-61, 2011.

BABIN, M.; STRAMSKI, D.; FERRARI, G.; CLAUSTRE, H.; BRICAUD, A.; OBOLENSKY, G.; HOEPFFNER, N. Variations in the light absorption coefficients of phytoplankton, nonalgal particles, and dissolved organic matter. J. Geophys. Res., v. 108, p. 4-11, 2003. 
BÍCEGO, M.; TANIGUCHI, S.; YOGUI, G.; MONTONE, R.; SILVA, D.; LOURENÇO, R.; MARTINS, C.; SASAKI, S.; PELLIZARI, V.; WEBER, R. Assessment of contamination by polychlorinated biphenyls and aliphatic and aromatic hydrocarbons in sediments of the Santos and São Vicente Estuary System, São Paulo, Brazil. Mar. Poll. Bull., v. 52, p. 1804-1816, 2006.

BRAGA, E. S.; MULLER, T. J. Observation of regeneration of nitrate, phosphate and silicate during upwelling off Ubatuba, Brazil, 23 S. Cont. Shelf Res., v. 18, p. 915-922, 1998.

BRAGA, E. S. Determinação automática de nitrito. In: WAGENER, A. R. L.; CARREIRA, R. Métodos analíticos de referência em Oceanografia Química. Rio de Janeiro, MMA/SMA. Cap. 6, p27-27, 1997a.

BRAGA, E. S. Determinação automática de nitrato. In: WAGENER, A. R. L.; CARREIRA, R. Métodos analíticos de referência em Oceanografia Química. Rio de Janeiro, MMA/SMA. Cap. 7, p 31-35, 1997b.

BRAGA, E. S.; BONETTI, C. V. D. H.; BURONE, L.; BONETTIFILHO, J. Eutrophication and bacterial pollution caused by industrial and domestic wastes at Baixada Santista Estuarine System- Brazil. Mar. Poll. Bull., v. 40, n. 2, p. 165-173, 2000.

BRAGA, E. S.; NIENCHESKI, L. F. H. Composição das massas de água e seus potenciais produtivos na área entre o Cabo de São Tomé (RJ) e o Chuí (RS). In: ROSSI-WONGTSCHOWSKI, C.L.B. \& L.S-P. MADUREIRA (Eds.). $O$ ambiente Oceanográfico da Plataforma Continental e do Talude na Região Sudeste-Sul do Brasil. EDUSP, São Paulo, 2006. p. 161-218.

BRAGA, E. S.; CHIOZZINI, V. G.; BERBEL, G. B. B.; MALUF, J. C. C.; AGUIAR, V. M. C.; CHARO, M.; MOLINA, D.; ROMERO, S. I.; EICHLER, B. B. Nutrient distributions over the Southwestern South Atlantic continental shelf from Mar del Plata (Argentina) to Itajaí (Brazil): Winter-summer aspects. Cont. Shelf Res., v. 28, p. 1649-1661, 2008.

CAMARGO, R.; HARARI, J.; MIRANDA, L. B. Modelagem numérica hidrodinâmica tridimensional da região costeira e estuarina de São Vicente e Santos (SP). Pesq. Naval (SDM), Rio de Janeiro, v. 15, p. 79-98, 2002.

CASTRO FILHO, B. M.; LEE, T. N. Wind forced sea level variability on the Southeast Brazilian Shelf. J. Geophys. Res., v. 100, p. 16045-16056, 1995.

CASTRO FILHO, B. M.; MIRANDA, L. B.; SILVA, L. S.; FONTES, R. F. C.; PEREIRA, A.F.; COELHO, A. L. Processos Físicos: Hidrografia, Circulação e Transporte. In: PIRESVANIN, A. M. S. (Ed), Oceanografia de um Ecossistema Subtropical: Plataforma de São Sebastião, SP. Editora da Universidade de São Paulo, São Paulo, 2008. p. 59-121.

CERDA, C.; CASTRO FILHO, B. M. Hydrographic climatology of South Brazil Bight shelf waters between Sao Sebastiao and Cape Sao Tome. Cont. Shelf Res., v. 89, p. 5-14, 2014.

CETESB. Sistema estuarino de Santos e São Vicente. PROCOP, CETESB, São Paulo, 2001, 176 p.

CETESB. Relatório da qualidade das águas interiores do Estado de São Paulo - 2009. São Paulo. Relatório Técnico Cetesb, 2010, v. 1, 310 p.

CONAMA - Conselho Nacional do Meio Ambiente. Resolução CONAMA $n^{\circ}$ 357, D.O.U.de 18.03.2005. s.1, p. 58-63, 2005.

GIANESELLA, S. M. F.; MIRANDA, L. B.; CORRÊA, F. M. P. S.; MOSER, G. A. O. Short -term variability and transport of nutrients and chlorophyll a in Bertioga, São Paulo state, Brazil. Braz. J.. Oceanogr., v. 53, p. 99-114, 2005.

GODOI, S. S; SCHMIDT, A. C. K.; MIRANDA, L. B. \& SILVEIRA, I. C. A., Características das massas de água do Sistema Corrente do Brasil, na região central do embaiamento de São Paulo. In: BRAGA, E. S. (Eds). Oceanografia e Mudanças Globais, III Simpósio Brasileiro de Oceanografia, São Paulo, 2006.p. 343-355.

GRASSHOFF, K. Determination of oxygen. In. GRASSHOFF, K.; KREMLING, K.; EHRHARDT, M. Methods of Seawater Analysis. 2nd ed. Weinheim: Verlag Chemie, 1983, 419 p.

GRASSHOFF, K.; KREMLING, K.; EHRHARDT, M. Methods of Seawater Analysis. 3rd ed. Weinheim: Wiley-VCH, 1999, $600 \mathrm{p}$.

HARARI, J.; FRANÇA, C. A. S.; CAMARGO, R. Climatology and hydrography of Santos estuary. In. NEVES, R; BARETTA, J.; MATEUS, M. (Orgs.). Perspective on integrated coastal zone management in South America. Portugal: IST Press. 2008.

HORTA, P. A.; BRASILEIRO, P. S.; BARROS-BARRETO, M. B.; FUJII, M. T. Subtidal benthic marine algae of the marine state park of Laje de Santos (São Paulo, Brazil). Braz. J. Oceanogr., v. 54, p. 225-234, 2006.

IBGE. Sinopse do censo demográfico 2010/IBGE. Rio de Janeiro. IBGE, 2011, $265 \mathrm{p}$.

IDSO, S. B.; GILBERT, R. G. On the universality of the Poole and Atkins Secchi disk-light extinction equation. J. Appl. Ecol., v. 11, p. 399-401, 1974.

LIVINGSTONE, D. R. The fate of organic xenobiotics in aquatic ecosystems: quantitative and qualitative differences in biotransformation by invertebrates and fish. Comp. Biochem. Physiol., v. 120, p. 43-39, 1998.

MARTINS, C. C; FERREIRA, J. A.; TANIGUCHI, S.; MAHIQUES, M. M.; BÍCEGO, M. C.; MONTONE, R. C. Spatial distribution of sedimentary linear alkylbenzenes and faecal steroids of Santos Bay and adjoining continental shelf, SW Atlantic, Brazil: Origin and fate of sewage contamination in the shallow coastal environment. Mar. Poll. Bull., v. 56, p.1359-1363, 2008.

MATSUURA, Y. Contribuição ao estudo sobre estrutura oceanográfica da região sudeste entre Cabo Frio (RJ) e Cabo de Santa Marta Grande (RS). Ciênc. Cult., Brazilian Assoc. Advan. Sci, v. 38, p. 1439-1450, 1986.

MOSER, G. A. O.; GIANESELLA, S. M. F.; BARRERA ALBA, J. J.; BÉRGAMO, A. L.; SALDANHA CORRÊA, F. M. P.; MIRANDA, L. B.; HARARI, J. Instantaneous transport of salt, nutrients, suspend matter and chlorophyll-a in the tropical estuarine system of Santos. Braz. J.. Oceanogr., v. 53, p. 115-127, 2005.

NEVES, T. Dossie de Gerenciamento do Parque Estadual Marinho da Laje de Santos, São Paulo: Instituto Florestal, Secretaria do Meio Ambiente, 1997, 425 p.

POOLE, H. H.; ATKINS, R. G. Photoelectric measurements of submarine illumination throughout the year. J. Marine Biol. Assoc., v. 16, p. 297-324, 1929.

PRASTKA, K., SANDERS, R., JICKELLS, T. Has the role of estuaries as sources or sinks of dissolved inorganic phosphorus changed over time? Results of Kd study. Mar. Poll. Bull., v. 36, p. 718-728, 1998. 
SILVA, P. S. C.; DAMATTO, S. R.; MALDONADO, C.; FÁVARO, D. I. T.; MAZZILLI, B. P. Metal distribution in sediment cores from São Paulo State Coast, Brazil. Mar. Poll. Bull., v. 62, p. 1130-1139, 2011.

SIQUEIRA, G. W.; LIMA, W. Z.; MENDES, A. S.; APRILE, F. M.; BRAGA, E. S.; MAHIQUES, M. M. Evolução do impacto ambiental causado por matéria orgânica, mercúrio e arsênio nos sedimentos de fundo do sistema estuarino de Santos. Geochim. Brasil, v. 18, p. 54-63, 2004.

SUTTI, B. O.; GUIMARAES, L. L.; SCHMIEGELOW, J. M. M.; BORGES, R. P. Nitrogen and organic matter in two rivers with different levels of impacts at the Santos estuarine system (Sao Paulo, Brazil). Braz. J Aquat. Sci. Technol., v. 20, p. 93104, 2016.
STRICKLAND, J. D. H.; PARSONS, T. R., 1972. A manual of seawater analysis. B. Fish. Res. Board Can., Ottawa, 1972, $184 \mathrm{p}$.

TRÉGUER, P.; Le CORRE, P. Manuel d'analyses des sels nutritifs dasn l'eau de mer. 2ème éd. Brest. Université de Bretagne Occidentale, 1975, $110 \mathrm{p}$

VALENTIN, J. L. Modelling of vertical distribution of marine primary biomass in the Cabo Frio upwelling region. Ciên. Cult., Brazilian Assoc. Advan. Sci, v. 44, p. 178-183, 1992. 